\title{
A cadaveric study on the rate of strain-dependent behaviour of human anterior cruciate ligament
}

\author{
M. MARIESWARAN ${ }^{1,2}$, ARNAB SIKIDAR $^{1}$, ABHISHEK RANA $^{1,3}$, DILPREET SINGH ${ }^{1,4}$ \\ NASIM MANSOORI ${ }^{5}$, SANJEEV LALWANI ${ }^{5}$, DINESH KALYANASUNDARAM ${ }^{1,6 *}$ \\ ${ }^{1}$ Centre for Biomedical Engineering, Indian Institute of Technology (IIT) Delhi, New Delhi, India. \\ ${ }^{2}$ Department of Sports Biomechanics, School of Sports Sciences, Central University of Rajasthan, Ajmer, India. \\ ${ }^{3}$ Department of Mechanical Engineering, IIT Delhi, New Delhi. \\ ${ }^{4}$ Centre for Advanced Manufacturing and Metrology, CSIR - Central Mechanical Engineering Research Institute, Durgapur, India. \\ ${ }^{5}$ Cadaver Training Research Facility (CTRF), Jai Prakash Narayan Apex Trauma Centre (JPNTC), \\ All India Institute of Medical Sciences (AIIMS), New Delhi, India. \\ ${ }^{6}$ Department of Biomedical Engineering, AIIMS, New Delhi, India.
}

\begin{abstract}
Purpose: Failure of anterior cruciate ligament often occurs in young sports personnel hampering their career. Such ACL ruptures are quite prevalent in sports such as soccer during dynamic loading which occurs at more than one rate of loading. In this work, a structural constitutive equation has been used to predict the forces acting on ACL for different rates of loading. Methods: Ligaments with distal femur and proximal tibia were subjected to tensile loading to avoid crushing of tissue ends and slipping at higher rates of strain. Custom designed cylindrical grippers were fabricated to clamp the distal femur and proximal tibial bony sections. To estimate parameters for the model, eighteen fresh cadaveric femur-ACL-tibia complex (FATC) samples were experimented on by pure tensile loading at three orders of rates of strain viz., $0.003,0.03$, and $0.3 \mathrm{~s}^{-1}$. The experimental force-elongation data was used to obtain parameters for De-Vita and Slaughter's equation. The model was validated with additional tensile experiments. Results: Statistical analysis demonstrated failure stress, Young's modulus and volumetric strain energy to vary significantly as a function of rate of strain. Midsection failure was observed only in samples tested at $0.03 \mathrm{~s}^{-1}$. Femoral or tibial insertion failure were observed in all other experiments irrespective of rate of strain. Conclusion: Human FATC samples were tensile tested to failure at three rates of strain using custom-designed cylindrical grippers. A structural model was used to model the data for the ACL behaviour in the linear region of loading to predict ligament behaviour during dynamic activities in live subjects.
\end{abstract}

Key words: femur-anterior cruciate ligament-tibia complex (FATC), rate of strain, tensile properties, structural model, force-length behaviour, dynamic loading

\section{Abbreviations}

ACL - Anterior Cruciate Ligament

FATC - Femur ACL tibia complex

\section{Introduction}

Being a prominent ligament in the knee joint anterior cruciate ligament (ACL) has the highest rate of injury [24]. Non-contact ACL injuries occur during (i) a sudden change in the direction of running at full or near full extension of the knee such as in soccer during plant and cut movement (ii) landing from a jump etc. [2]. ACL is a viscoelastic soft tissue whose failure force and elongation vary as a function of the rate of strain or rate of loading. For a material exhibiting viscoelastic behaviour, the failure force increases with the rate of strain, while the elongation at failure decreases with an increase in the rate of strain [27]. The viscoelastic behaviour can be modelled with short-term and long-term variables. The short-term variables are rate of strain-dependent, while the long-term variables involving time constants are dependent on the stress relaxation of the material [1]. A structural model relating the stress on the liga-

* Corresponding author: Dinesh Kalyanasundaram, 298, Block 2, Indian Institute of Technology Delhi, Hauz Khas - 10016, New Delhi, India. Phone: 011-2659-7344, e-mail: dineshk.iitdelhi@gmail.com

Received: June 5th, 2020

Accepted for publication: December 17th, 2020 
ment as a function of the rate of strain was proposed by De Vita and Slaughter [29]. Further, the parameters used in the structural model are related to the tissue's structure. Hence, the structural model is entirely coherent as the tissue morphology is taken into account. Other types of mathematical models, including phenomenological models, however, do not relate directly to the tissue morphology [23], [25].

In order to simulate dynamic activities, the need for the rate of strain dependent force-length behaviour is cardinal. Tensile stretch-induced failure or rupture of human ACL, as well as femur - ACL- tibia complex (FATC), has been studied earlier, either at quasi-static rate of strain (i.e., very low rates of strain in the order of $0.075 \mathrm{~s}^{-1}$ or lesser) or at very high rates of strain $\left(1 \mathrm{~s}^{-1}\right)$. Currently, the number of studies reported on the tensile characteristics of human FATC samples at various rates of strain are quite scarce [15], [16]. Hence, experimentation of ACL at various rates of strain is essential.

Cadaveric studies on human knee ligaments were performed by various research groups for understanding the injury mechanics of pedestrian crash accidents [3], [17]-[19]. In Table 1, studies on tensile testing of human/animal ACL tissues at single and multiple rates of strain are reported. Details on the rate of strain used, number of samples, age and sex of subjects, methods of sample preservation, preparation, testing and significant findings of studies were summarized in the Table 1. However, the study on human FATC has been reported only by a few research groups [21], [28], [30]. The authors had tested FATC for a given rate of strain. Arnoux et al. [3] reported tensile testing of human isolated knee cruciate and collateral ligaments potted in resin at $2 \mathrm{~ms}^{-1}$ speed corresponding to the impact injury on knee in pedestrians during accidents. Mo et al. studied the effects of automobile crash on pedestrian knee ligaments. Lateral impact on knee and tibia (on different locations) were evaluated for high-speed impact. The data obtained from these studies were used to obtain the parameters for a finite element model [3], [17]-[19]. Chandrashekar et al. [5] evaluated the effect of sex on the tensile properties of ACL. All of the above-mentioned tensile studies were performed on one given rate of strain, and hence the development of a mathematical model was not feasible. Only Kennedy et al. [11] reported tensile testing of human ACL for two rates of strain. Recent articles are focused more on simulating running or walking kinematics in an isolated cadaver leg and observing the failure mechanics [12], [13].

The significance of the current study is to understand the behaviour of human ACL at multiple rates of strain and adopt a structural constitutive model to predict forces acting on it. When various kinematics are performed involving lower limb, the anterior cruciate ligament at the knee joint is loaded at different rates. Hence, experimental force-elongation data on eighteen fresh cadaveric femur-anterior cruciate ligament-tibial complex (FATC) were obtained at three rates of strain $\left(0.003,0.03\right.$ and $\left.0.3 \mathrm{~s}^{-1}\right)$. This experimental data was used to obtain parameters for the structural model. To validate the constitutive model, additional experiments were conducted.

\section{Materials and methods}

\subsection{Sample acquisition and preparation}

In Figure 1, the experimental and modeling workflow in brief are described. Samples obtained during the autopsy of unclaimed bodies at All India Institute of Medical Sciences, New Delhi, were used for this study. Eighteen FATC samples were obtained from nine fresh-frozen cadavers (during the autopsy). Cadaveric knee samples of human male subjects aged between 60 and 70 years were used in this study. Only male subjects' samples were used in this limited study due to scarcity of female cadaveric samples. Subjects with knee deformity, tuberculosis and osteoarthritis (evaluated by visual observation) were excluded from the study. Details on design of cylindrical gripper has been provided in the supplementary section.

All necessary ethical approval and documentation were carried out in obtaining the samples. The knee of the cadavers were dissected from the cadavers at four inches above the knee joint on the femur and four inches below the knee joint on the tibia. Patella and patellar tendon were removed at the time of dissection. Lateral collateral ligament, medial collateral ligament, and posterior cruciate ligament were severed, while fat tissues were removed, leaving merely the ACL intact, which constitutes the FATC sample. Only samples with intact ACL without any deformation or hole at insertion regions were used for the experiments. A universal testing machine (model: Tinius Olsen, H5K5, UK), with a maximum load cell of $5 \mathrm{kN}$ was used to perform the tensile test at a sampling frequency of $100 \mathrm{~Hz}$. Pre-conditioning of samples was not performed before testing. The resting length and cross-sectional area of samples tested at three rates of strain are reported in the Table SI in supplementary section. Post experimentation, the samples were disposed at department of anatomy. 
Table 1. List of rate of strain studies on human and animal ACL/FATC

\begin{tabular}{|c|c|c|c|c|}
\hline $\begin{array}{l}\text { Reference } \\
\text { number }\end{array}$ & $\begin{array}{c}\text { Sample source, } \\
\text { method of gripping, } \\
\text { age of subject }\end{array}$ & $\begin{array}{l}\text { Sample preservation, } \\
\text { experiment protocols }\end{array}$ & $\begin{array}{l}\text { Rates of strain, } \\
\text { (number } \\
\text { of samples used) }\end{array}$ & $\begin{array}{l}\text { Observation } \\
\text { /remarks }\end{array}$ \\
\hline 1 & 2 & 3 & 4 & 5 \\
\hline [20] & $\begin{array}{l}\text { FATC from male } \\
\text { rhesus monkey were } \\
\text { experimented. } \\
\text { Details on the age } \\
\text { of animals, were not } \\
\text { provided. }\end{array}$ & $\begin{array}{l}\text { Samples were tested as right-left pairs. One } \\
\text { sample was strained at lower rate of strain } \\
\text { and the other at higher rate of strain. } \\
\text { Samples were used immediately after } \\
\text { sacrificing the animal. Six contoured } \\
\text { serrated grips were used to fix tibia } \\
\text { and femur at } 135^{\circ} \text { with reference to each } \\
\text { other. Steinmann pins were passed through } \\
\text { the hole drilled in the middle of the bones. } \\
\text { The entire set up was mounted on the slotted } \\
\text { plate attached to the testing machine. }\end{array}$ & $\begin{array}{l}0.662(n=17) \\
\text { and } 0.00662(n=17)\end{array}$ & $\begin{array}{l}\text { Difference between } \\
\text { the Force-deformation } \\
\text { plots for different rates } \\
\text { of strain occurs after the } \\
\text { linear region. At faster } \\
\text { loading rate } 2 / 3 \text { rd } \\
\text { of specimens were } \\
\text { ligamentous failure } \\
\text { and remaining } 1 / 3 \text { rd, } \\
\text { were tibial avulsion } \\
\text { fracture. At slower rate, } \\
\text { it was reverse [20]. }\end{array}$ \\
\hline [11] & $\begin{array}{l}\text { Human isolated ACL. } \\
\text { Details on the sex } \\
\text { of samples were } \\
\text { not mentioned. } \\
\text { Age }-20-75 \text { years. }\end{array}$ & $\begin{array}{l}\text { Samples were wrapped in gauze and soaked } \\
\text { in isotonic saline. Sample were collected } \\
\text { within } 12 \text { hours of death and experimented } \\
\text { within } 4 \text { hours of harvest. The ligament was } \\
\text { fixed to upper clamp initially and allowed } \\
\text { to hang freely along its orientation. Then the } \\
\text { lower clamp was applied. Care was taken not } \\
\text { to have twists in the sample while clamping } \\
\text { and testing. }\end{array}$ & $\begin{array}{l}0.075(n=10) \\
\text { and } 0.3(n=10) / \mathrm{s} .\end{array}$ & $\begin{array}{l}\text { Bone-ligament junction } \\
\text { is the weakest in the } \\
\text { FATC, hence testing } \\
\text { of isolated ligaments } \\
\text { was preferred. At higher } \\
\text { rate of strain, failure } \\
\text { is ligamentous. Failure } \\
\text { load and strain increased } \\
\text { for higher rate of strain } \\
\text { [11]. }\end{array}$ \\
\hline [21] & $\begin{array}{l}\text { Human FATC, Young } \\
\text { age } 16-26, \text { old age } \\
\text { 48-86, samples were } \\
\text { obtained from both } \\
\text { male and female } \\
\text { donors. }\end{array}$ & $\begin{array}{l}\text { Samples were obtained during autopsy } \\
\text { or amputation and preserved at }-4^{\circ} \mathrm{C} \text { for } \\
\text { a week and }-15^{\circ} \mathrm{C} \text { for four weeks. The } \\
\text { sample loading and testing procedure used } \\
\text { in earlier published work ([20]) } \\
\text { of the research group were followed. }\end{array}$ & $\begin{array}{l}1 \mathrm{~s}^{-1}, n=6 \text { for young } \\
\text { age group and } n=2 \\
- \text { for old age group }\end{array}$ & $\begin{array}{l}\text { Younger subjects } \\
\text { reported failure force, } \\
\text { energy to failure } \\
\text { and Young's modulus } \\
\text { two to three times } \\
\text { higher than the older } \\
\text { subjects did [21]. }\end{array}$ \\
\hline [30] & $\begin{array}{l}\text { Human FATC, young } \\
\text { age } 22-35 \text { years, } \\
\text { middle age } 40-50 \text { years, } \\
\text { old age } 60-97 \text { years. } \\
\text { Sex of the subject } \\
\text { was not mentioned. }\end{array}$ & $\begin{array}{l}\text { Knee samples were obtained during autopsy } \\
\text { and stored at }-20^{\circ} \mathrm{C} \text {. Before } \\
\text { experimentation, the samples were thawed } \\
\text { for } 24 \text { hours at room temperature. All soft } \\
\text { tissues except ACL were removed. Femur } \\
\text { and tibia were cut } 15 \mathrm{~cm} \text { from the joint line } \\
\text { and fixed to an aluminium cylinder using } \\
6 \mathrm{~mm} \text { bolts. One FATC from a cadaver was } \\
\text { tested in tibial orientation, } \\
\text { and the contralateral FATC was tested } \\
\text { in anatomical orientation. Samples were } \\
\text { tested at } 30^{\circ} \text { flexion angle. ACL tissue } \\
\text { was kept moist using physiological saline } \\
\text { solution during sample preparation and testing. }\end{array}$ & $\begin{array}{l}0.1 \mathrm{~s}^{-1}, n=10 \\
\text { in each age and } \\
\text { orientation group. }\end{array}$ & $\begin{array}{l}\text { Effect of age of subject } \\
\text { and orientation } \\
\text { of sample (anatomical } \\
\text { and tibial) on the } \\
\text { mechanical properties } \\
\text { were evaluated. Higher } \\
\text { failure force and stiffness } \\
\text { were observed for } \\
\text { samples obtained from } \\
\text { younger subjects } \\
\text { and for samples tested } \\
\text { in anatomical orientation } \\
\text { [30]. }\end{array}$ \\
\hline [28] & $\begin{array}{l}\text { Human FATC, age } \\
29-55 \text { years, sex } \\
\text { of the subject } \\
\text { was not mentioned. }\end{array}$ & $\begin{array}{l}\text { Samples were obtained from autopsy } \\
\text { and tested immediately. Femur and tibia } \\
\text { were cut } 15 \mathrm{~cm} \text { from the joint line. All soft } \\
\text { tissues except ACL were removed. Femur } \\
\text { and tibia were potted in methylmethacrylate } \\
\text { and held in position using special grippers. }\end{array}$ & $0.03 \mathrm{~s}^{-1}, n=10$ & $\begin{array}{l}\text { The average values } \\
\text { for failure force } \\
\text { and stiffness were } \\
634 \mathrm{~N} \text { and } 144 \mathrm{~N} \mathrm{~mm}^{-1} \\
{[28] .}\end{array}$ \\
\hline [3] & $\begin{array}{l}\text { Human ACL with bone } \\
\text { plugs, age - } \\
60-90 \text { years, samples } \\
\text { were obtained from } \\
\text { both male and female } \\
\text { donors. }\end{array}$ & $\begin{array}{l}\text { Cadavers preserved using Winkler's solution } \\
\text { were used for this study. After dissection, } \\
\text { the knee samples were preserved at } 3^{\circ} \mathrm{C} \text {. } \\
\text { On the day of testing, samples were thawed } \\
\text { in room temperature for } 3 \text { hours. The bone } \\
\text { plugs were fixed in resin and mounted. }\end{array}$ & $66.6 \mathrm{~s}^{-1}, n=4$ & $\begin{array}{l}\text { Tensile testing of knee } \\
\text { ligaments at high rate } \\
\text { of strain was performed } \\
\text { to study failure } \\
\text { of ligaments during } \\
\text { pedestrian impact. } \\
\text { Stiffness and Young's } \\
\text { modulus were reported } \\
\text { in the following range } \\
\text { - } 50 \text { to } 145 \mathrm{Nm}^{-1} \\
\text { and } 25 \text { to } 210 \mathrm{MPa}[3] .\end{array}$ \\
\hline
\end{tabular}




\begin{tabular}{|c|l|l|l|l|}
\hline $\mathbf{1}$ & \multicolumn{1}{|c|}{$\mathbf{2}$} & \multicolumn{1}{|c|}{$\mathbf{3}$} & \multicolumn{1}{c|}{$\mathbf{4}$} & \multicolumn{1}{|c|}{$\mathbf{5}$} \\
\hline$[5]$ & $\begin{array}{l}\text { Human ACL with bone } \\
\text { plugs, age 26-50 } \\
\text { years for male subjects, } \\
17-50 \text { for female } \\
\text { subjects. }\end{array}$ & $\begin{array}{l}\text { Knee samples were harvested within } \\
12 \text { hours after death and preserved at } \\
-20^{\circ} \mathrm{C} \text {. Femur and tibia were cut 3 inches } \\
\text { from the ACL attachment site. The lateral } \\
\text { and medial edges of the cut femur and tibial } \\
\text { fragments were cut parallel to the longitudinal } \\
\text { axis of ACL. Bone plugs were potted } \\
\text { in aluminium cylinders using cerrobend. The } \\
\text { Tibial bone plug was oriented at 45 }{ }^{\circ} \text { to the } \\
\text { longitudinal axis of ACL and tested. }\end{array}$ & $\begin{array}{l}1 \mathrm{~s}^{-1}, n=8 \\
(\text { samples from female), } \\
n=9 \\
\text { (samples from male) })\end{array}$ & $\begin{array}{l}\text { Tensile properties of ACL } \\
\text { samples obtained from } \\
\text { male and female } \\
\text { subjects were compared. } \\
\text { Samples obtained from } \\
\text { male subjects reported } \\
\text { higher tensile properties } \\
\text { compared to samples } \\
\text { obtained from female } \\
\text { subjects [5]. }\end{array}$ \\
\hline
\end{tabular}

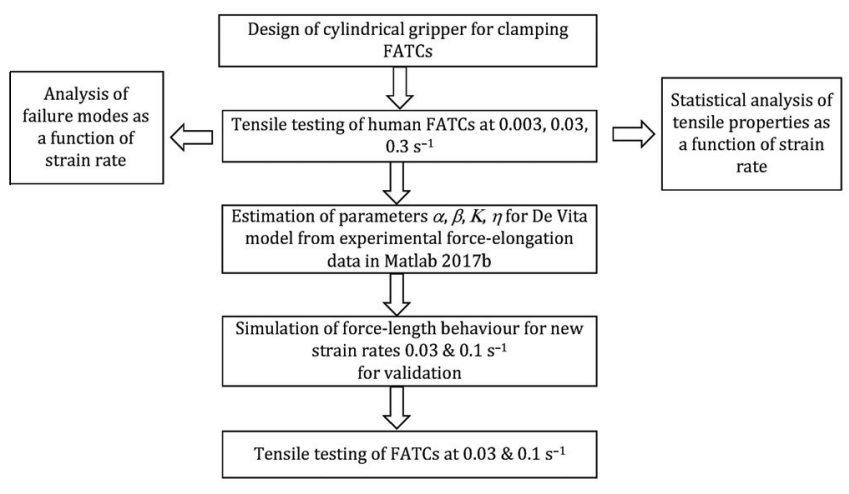

Fig. 1. Flowchart depicting the process followed in the study

\subsection{Tensile experiments at various rates of strains}

The rate of strain was calculated from the ratio of crosshead speed $\left(\mathrm{mm} \cdot \mathrm{s}^{-1}\right)$ to the average length of the ACL sample $(30 \mathrm{~mm})$. Three crosshead speeds of 0.083 , 0.83 , and $8.33 \mathrm{~mm} \cdot \mathrm{s}^{-1}$ were selected for the study. The corresponding mean rate of strain for each experi- mental group can be approximated to $0.003,0.03$ and $0.3 \mathrm{~s}^{-1}$. The highest rate of strain of the universal testing machine and two orders below the maximum rate of strain were chosen for the study. This range is reported to include the rates of strain at which dynamic activities occur in knee ligaments [7]. Cleaned FATC samples were loaded in the universal testing machine using the cylindrical grippers (Fig. 2). The tensile experiments were performed until failure to obtain the elongation behaviour as a function of applied force with a single loading cycle. As other ligaments and soft tissues have been removed before the tensile tests, the loading tends to act in line or very close to the axial direction of the ligament. Hence, the loading direction in the current FATC experiments is slightly different from the loading direction in real-life conditions. Zero-degree extension of the knee joint is approximately maintained at the start of the tensile experiments. The gripping method allows for unidirectional translation of femur and tibia in superiorinferior direction and not in other planes. The crosssectional diameter and length of ACL were measured using digital vernier caliper, before the start of the

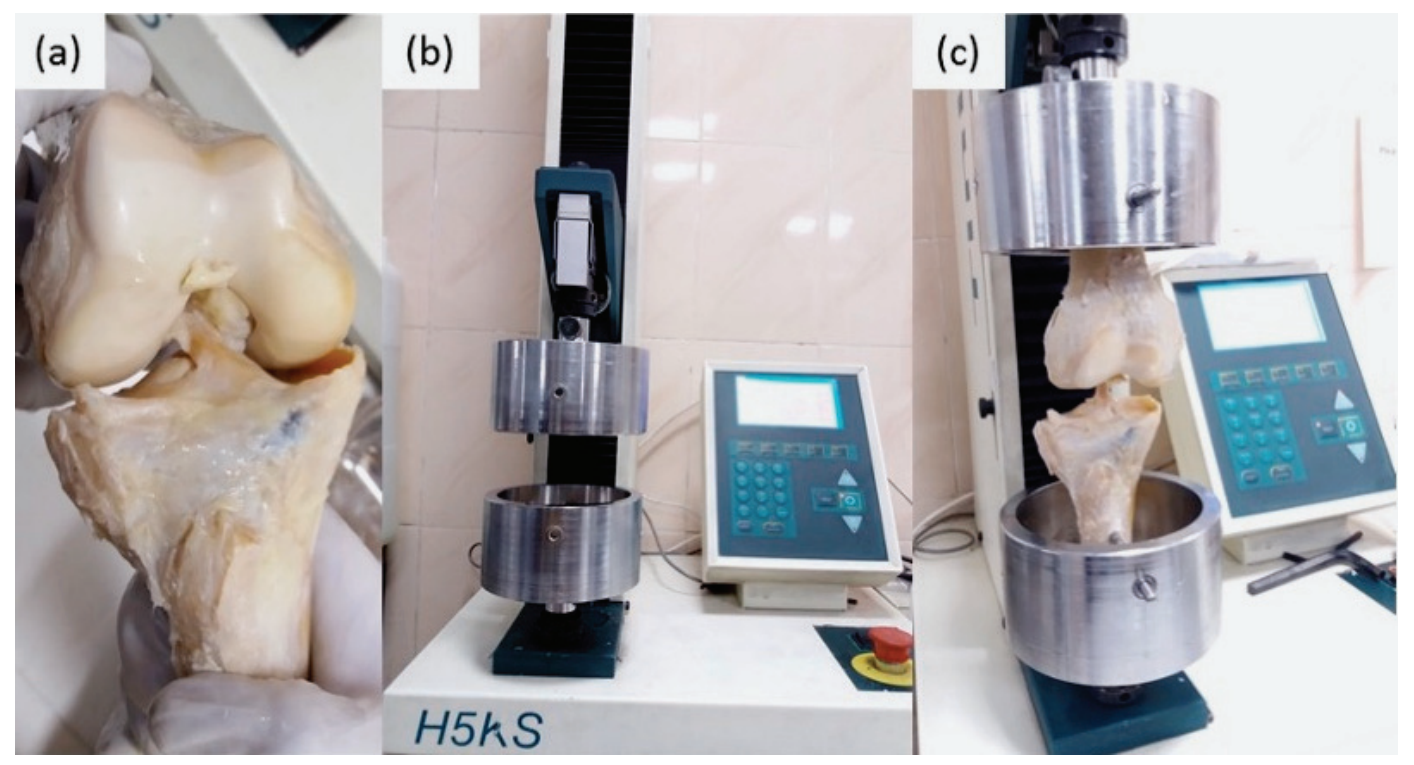

Fig. 2. (a) Femur-ACL-Tibia Complex, (b) gripper, and (c) sample loaded in cylindrical gripper 
experiments. The length of the ligaments was measured after rotating the femur laterally (to get the full view of ACL). Approximate location of the midpoint of the insertion regions was identified and the distance between them was measured. The width of the ligament tissue at the femoral insertion point and thickness of the tissue in midsection on the ligament were measured. The product of the measured width and thickness yields an approximate cross-sectional area. It should also be noted that the human ACL tissue has an irregular geometry and hence requires some approximations for calculation of the cross-sectional area. Also, to eliminate the errors arising from the calculations of cross-sectional area, only the force versus elongation values were used to obtain the parameters for the mathematical model.

For each of the three rates of strain, six samples were tensile tested until failure. The samples were randomly assigned to three different rates of strain. The point of failure for each sample was noted down for each sample. Details on the De Vita and slaughter model used for capturing rate of strain behaviour is provided in the supplementary section.

\subsection{Statistical analysis}

Statistical analysis was performed to observe the variations in the tensile properties measured at different rates of strain. As there were three gropus
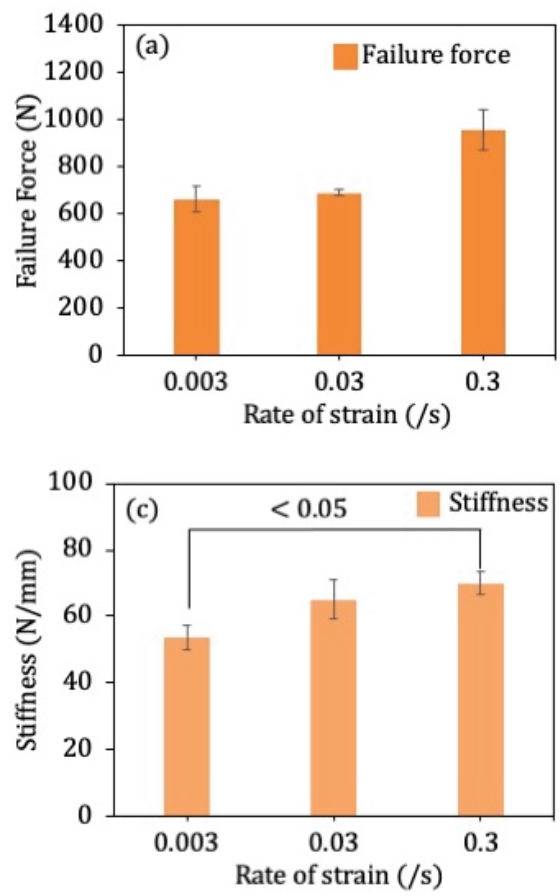

(three rates of strain) of tensile properties, KruskalWallis $H$-test (non-parametric equivalent of OneWay ANOVA) was selected for the statistical analysis. As per the reference cited, the number of samples in each group shall be greater than 5 [6]. Hence, the tests have been conducted on 6 samples per rate of strain. Two-stage analysis consisting of KruskalWallis $H$-test and Mann-Whitney $U$-test were performed on the tensile properties. The tests were carried out using IBM SPSS (IBM Analytics, Chicago, Illinois, USA).

\section{Results}

The numerical values of the tensile properties for each sample are reported in Table S2 and S3 in supplementary section. The variation of average values of the measured tensile properties as a function of rates of strain are reported in Figs. 3 and 4. The mean, median, and results of the Kruskal-Wallis $H$-test for tensile properties measured at three rates of strain are reported in Table 2. Values of stiffness, failure stress, Young's modulus, and volumetric strain energy were observed to be varying significantly across rates of strain (in Kruskal-Wallis $H$-test) indicating that at least values at one of the three rates of strain differ significantly from values at other rates of strain $\left(\mathrm{s}^{-1}\right)$. Multiple pairwise comparisons using the
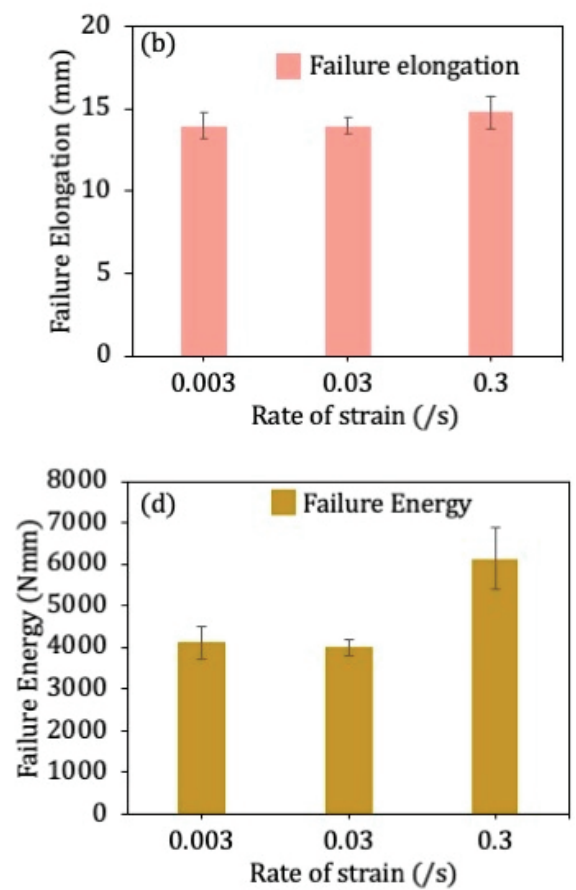

Fig. 3. Variation of: (a) failure force, (b) failure elongation, (c) stiffness, and (d) failure energy 

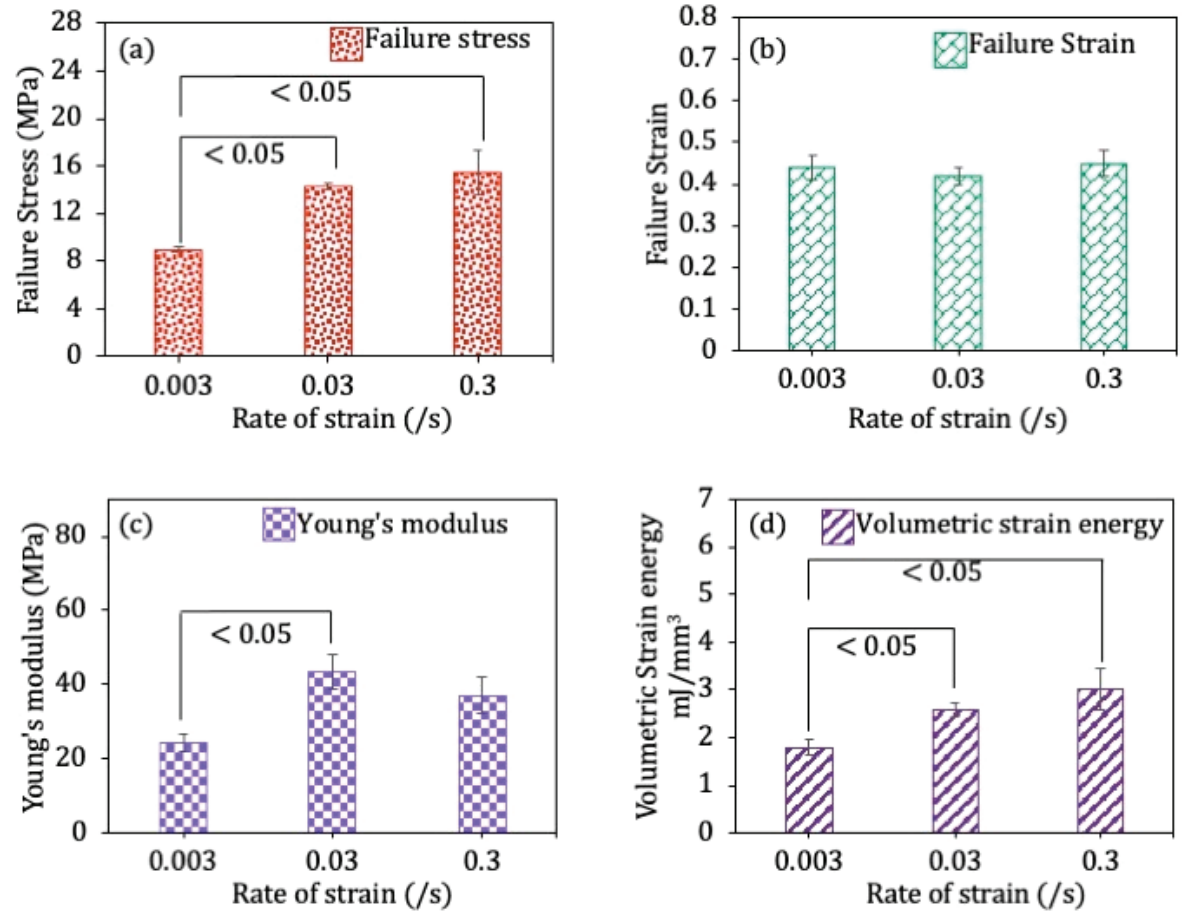

Fig. 4. Variation of: (a) failure stress, (b) failure strain, (c) Young's modulus, and (d) Volumetric strain energy

Table 2. Overall $p$-value by Kruskal-Wallis $H$-test for tensile properties at various rates of strain

\begin{tabular}{|c|c|c|c|c|c|c|c|c|}
\hline \multirow{3}{*}{$\begin{array}{c}\text { Tensile } \\
\text { Properties }\end{array}$} & \multicolumn{6}{|c|}{ Rate of strain $\left(\mathrm{s}^{-1}\right)$} & \multicolumn{2}{|c|}{$\begin{array}{c}\text { Kruskal-Wallis } \\
H \text {-test }\end{array}$} \\
\hline & \multicolumn{2}{|c|}{$0.003(\mathrm{~A})$} & \multicolumn{2}{|c|}{0.03 (B) } & \multicolumn{2}{|c|}{$0.3(\mathrm{C})$} & \multirow[b]{2}{*}{$\psi^{2}$} & \multirow[b]{2}{*}{$P$} \\
\hline & Mean \pm SEM & $\begin{array}{l}\text { Median } \\
\text { (Min-max) }\end{array}$ & Mean \pm SEM & $\begin{array}{l}\text { Median } \\
\text { (Min-max) }\end{array}$ & Mean \pm SEM & $\begin{array}{l}\text { Median } \\
\text { (Min-max) }\end{array}$ & & \\
\hline $\begin{array}{l}\text { Failure } \\
\text { force }[\mathrm{N}]\end{array}$ & $659.96 \pm 54.18$ & $\begin{array}{c}661.15 \\
(440.50-841.00) \\
\end{array}$ & $688.44 \pm 15.62$ & $\begin{array}{c}681.97 \\
(645.60-756.80)\end{array}$ & $954.33 \pm 87.23$ & $\begin{array}{c}984.00 \\
(594.00-1173.00) \\
\end{array}$ & 5.836 & 0.054 \\
\hline $\begin{array}{l}\text { Failure } \\
\text { elongation [mm] }\end{array}$ & $13.96 \pm 0.80$ & $\begin{array}{c}14.26 \\
(10.71-16.69) \\
\end{array}$ & $13.95 \pm 0.49$ & $\begin{array}{c}13.47 \\
(12.85-15.61)\end{array}$ & $14.77 \pm 0.97$ & $\begin{array}{c}15.31 \\
(10.21-16.89)\end{array}$ & 1.766 & 0.414 \\
\hline $\begin{array}{l}\text { Stiffness } \\
{\left[\mathrm{N} \cdot \mathrm{mm}^{-1}\right]}\end{array}$ & $53.74 \pm 3.63$ & $\begin{array}{c}53.25 \\
(42.94-69.16) \\
\end{array}$ & $64.87 \pm 5.92$ & $\begin{array}{c}63.45 \\
(46.81-87.20) \\
\end{array}$ & $69.92 \pm 3.38$ & $\begin{array}{c}69.28 \\
(60.90-80.56) \\
\end{array}$ & 6.678 & 0.035 \\
\hline $\begin{array}{l}\text { Failure } \\
\text { energy [N.mm] }\end{array}$ & $4113.35 \pm 380.43$ & $\begin{array}{c}4181.26 \\
(2919.28-5449.92) \\
\end{array}$ & $3994.80 \pm 195.48$ & $\begin{array}{c}4086.25 \\
(3256.41-4495.50)\end{array}$ & $6137.64 \pm 733.33$ & $\begin{array}{c}6900.10 \\
(2687.34-7391.88) \\
\end{array}$ & 5.064 & 0.079 \\
\hline $\begin{array}{l}\text { Failure } \\
\text { stress (MPa) }\end{array}$ & $8.94 \pm 0.24$ & $\begin{array}{c}8.78 \\
(8.25-10.02) \\
\end{array}$ & $14.30 \pm 0.30$ & $\begin{array}{c}14.13 \\
(13.35-15.25) \\
\end{array}$ & $15.46 \pm 1.93$ & $\begin{array}{c}15.49 \\
(8.84-21.52) \\
\end{array}$ & 10.246 & 0.006 \\
\hline Failure strain & $0.44 \pm 0.03$ & $\begin{array}{c}0.44 \\
(0.31-0.55)\end{array}$ & $0.42 \pm 0.02$ & $\begin{array}{c}0.42 \\
(0.36-0.52)\end{array}$ & $0.45 \pm 0.03$ & $\begin{array}{c}0.47 \\
(0.29-0.54)\end{array}$ & 1.211 & 0.546 \\
\hline $\begin{array}{l}\text { Young's } \\
\text { modulus (MPa) }\end{array}$ & $24.39 \pm 2.17$ & $\begin{array}{c}25.51 \\
(15.69-30.87) \\
\end{array}$ & $43.48 \pm 4.67$ & $\begin{array}{c}42.22 \\
(27.71-57.28) \\
\end{array}$ & $36.97 \pm 4.90$ & $\begin{array}{c}41.38 \\
(18.54-48.78) \\
\end{array}$ & 7.240 & 0.027 \\
\hline $\begin{array}{l}\text { Volumetric } \\
\text { strain energy } \\
\left(\mathrm{mJ} \cdot \mathrm{mm}^{-3}\right)\end{array}$ & $1.8 \pm 0.15$ & $\begin{array}{c}1.93 \\
(1.07-2.06)\end{array}$ & $2.57 \pm 0.14$ & $\begin{array}{c}2.63 \\
(2.06-2.99)\end{array}$ & $3.02 \pm 0.44$ & $\begin{array}{c}3.11 \\
(1.55-4.76)\end{array}$ & 8.433 & 0.015 \\
\hline
\end{tabular}

Mann-Whitney $U$-test were performed for tensile properties, which were significant in Kruskal-Wallis $H$-test. The results of the multiple pairwise comparisons are provided in Table 3. The pairs, which are significantly different from each other, are indicated in Fig. 4. The values of tensile properties were sig- nificantly different for the following rates of strain pairs $0.003 \mathrm{~s}^{-1}$ versus $0.03 \mathrm{~s}^{-1}$ and $0.003 \mathrm{~s}^{-1}$ versus $0.3 \mathrm{~s}^{-1}$. In Figure 5, the failure modes of FATC samples tested at various rates of strain are reported. Femoral insertion and tibial insertion failure were observed at 0.0003 and $0.3 \mathrm{~s}^{-1}$. At $0.03 \mathrm{~s}^{-1}$, all three 


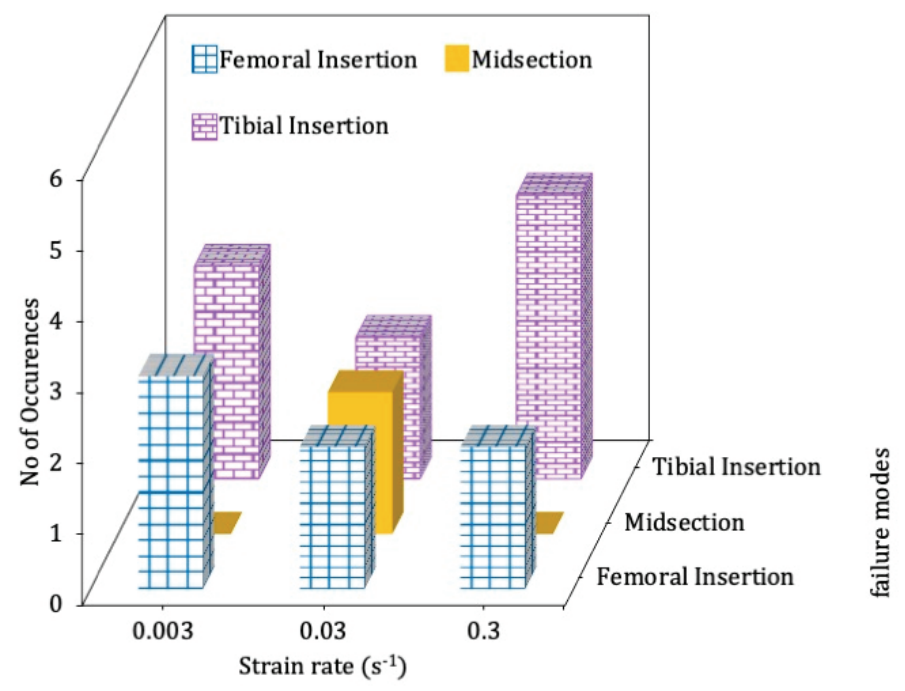

Fig. 5. Failure modes of FATC as a function of strain rate used for tensile testing until failure

(a)

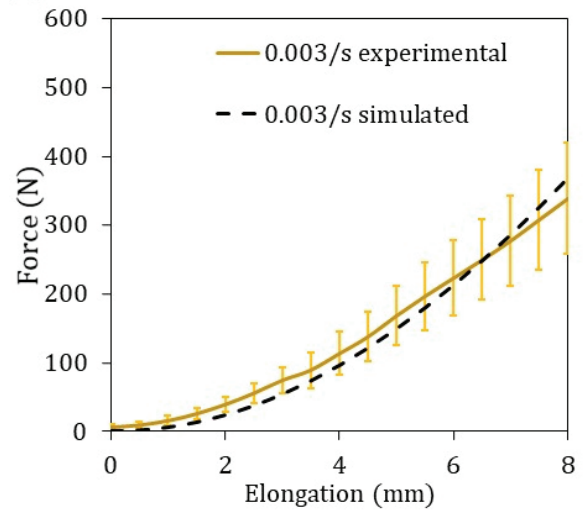

(c)

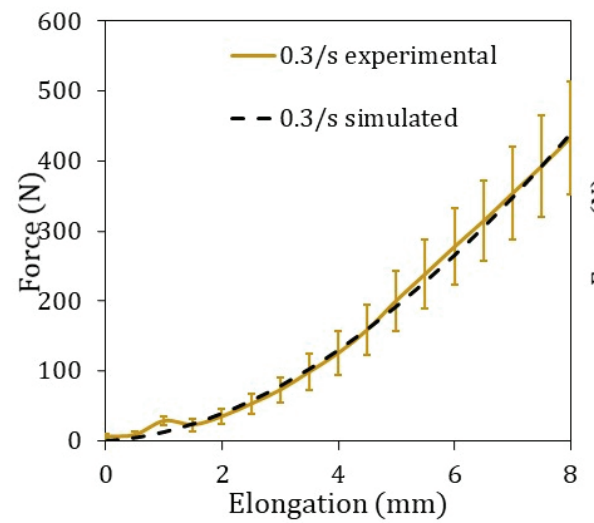

(b)

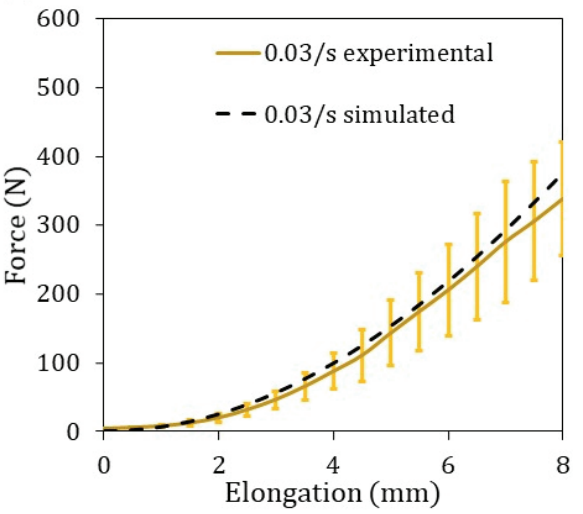

(d)

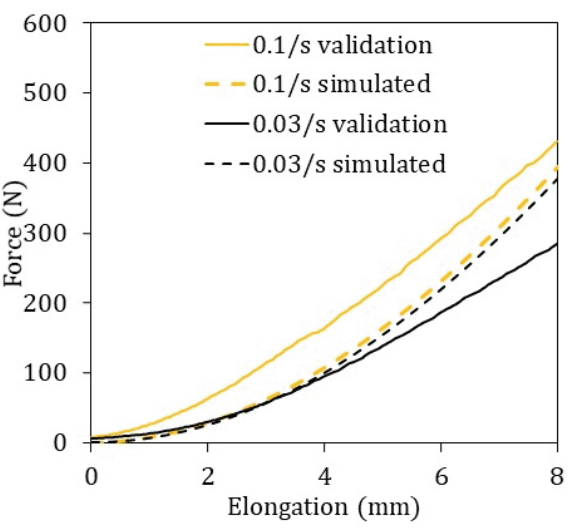

Fig. 6. Simulated and average experimental force-length behaviour of FATC at: (a) $0.003 \mathrm{~s}^{-1}$, (b) $0.03 \mathrm{~s}^{-1}$, (c) $0.3 \mathrm{~s}^{-1}$ and (d) Validation of model: Simulated and experimental force-length behaviour of FATC at $0.03 \mathrm{~s}^{-1}$ and $0.1 \mathrm{~s}^{-1}$

modes of failure (including midsection failure) were equally observed.

The parameters of the constitutive equation for variable rate of strain experiments were estimated numerically [29]. The values of the parameters to best fit the experimental data were $\alpha=1.14, \beta=2.0, \eta=$ $70 \mathrm{MPa} \cdot \mathrm{s}^{-1}$, and $K=1000 \mathrm{MPa}$. The average experi- mental data and model-simulated data (till 30\% strain) for the three rates of strain are shown in Figs. $6 a, b$ and c. For the validation of the model, simulation of the force vs. elongation was carried out for 0.03 and $0.1 \mathrm{~s}^{-1}$. Later, experiments were performed at 0.03 and $0.1 \mathrm{~s}^{-1}$ to confirm the prediction. The plot is shown in Fig. 6d. 
Table 3. Pairwise comparisons (Mann-Whitney $U$-test) for stiffness, failure stress, Young's modulus and volumetric strain energy

\begin{tabular}{|c|c|c|c|}
\hline Stiffness [N/mm] & A & B & C \\
\hline A & NA & & \\
\hline B & 0.093 & NA & \\
\hline C & $\mathbf{0 . 0 1 5}$ & 0.394 & NA \\
\hline Failure stress [MPa] & A & B & C \\
\hline A & NA & & \\
\hline B & $\mathbf{0 . 0 0 2}$ & NA & \\
\hline C & $\mathbf{0 . 0 0 9}$ & 0.589 & NA \\
\hline Young's modulus [MPa] & A & B & C \\
\hline A & NA & & \\
\hline B & $\mathbf{0 . 0 0 4}$ & NA & \\
\hline C & 0.132 & 0.485 & NA \\
\hline $\begin{array}{c}\text { Volumetric strain energy } \\
{\left[\mathrm{mJ} \cdot \text { mm }^{-3}\right]}\end{array}$ & A & B & C \\
\hline A & NA & & \\
\hline B & $\mathbf{0 . 0 0 2}$ & NA & \\
\hline C & $\mathbf{0 . 0 4 1}$ & 0.310 & NA \\
\hline
\end{tabular}

\section{Discussion}

\subsection{Effect of rate of strain}

In the current study, the failure force of FATC was observed to be higher with an increase in the rate of strain. This behaviour of samples is close to the behaviour of ideal viscoelastic material, as reported in the literature [4]. In a previous study reported by Kennedy et al. [11] on human ACL (the only rate of strain study on human ACL), an increase in both failure force and elongation at failure were observed at higher rates of strain. This is not in accordance with a typical viscoelastic behaviour and can be attributed to the use of isolated ACL samples. In Table 4, the human cadaveric studies on ACL with details on rate of strain used, mechanical properties, nature of the sample and age of the subject are summarized. Kennedy et al. [11] had reported tensile testing of human ACL at multiple rates of strain. However, other research works involving single rate of strain study of human cadaveric ACL are also provided in the Table 4.

The average values of failure force and energy for failure from the current study are in range with those values from the literature for the age group and rate of strain involved [11], [21], [28]. Average failure force reported by Trent et al. [28] at $0.03 \mathrm{~s}^{-1}$ has been observed to match the corresponding values in the current study for the same rate of strain. Average failure forces reported in the current study at $0.3 \mathrm{~s}^{-1}$ has been approximately by $300 \mathrm{~N}$ higher than the corresponding value reported by Kennedy et al. [11] for the same rate of strain. Woo et al. [30] has tested FATC of old aged subjects (60-97 years) in anatomical orientation at $0.1 \mathrm{~s}^{-1}$ and reported failure force values similar to the ones reported in the current study for 0.003 and $0.03 \mathrm{~s}^{-1}$. Noyes and Grood have experimented human FATC at $1 \mathrm{~s}^{-1}$ from old aged subjects and reported failure force values comparable to the corresponding values at $0.3 \mathrm{~s}^{-1}$ from the current study [21]. Chandrashekar et al. [5] tested ACL bone plugs from the male subjects (aged 26-50) at $1 \mathrm{~s}^{-1}$. They reported failure force twice the magnitude obtained in the current study for FATC obtained from male subjects (aged 60-70) tested at $0.3 \mathrm{~s}^{-1}$.

Failure elongation has been reported only by two research groups [5], [11]. The average value of failure elongation reported in the current study is approximately 4 to $5 \mathrm{~mm}$ higher than the corresponding values reported by Kennedy et al. [11] and Chandrashekar et al. [5]. In the current study, the femur condyles were made to touch the tibial plateau in the extended knee position. The samples were loaded from this point. The initial data points with negligible force values were discarded. Kennedy et al. [11] experimented on isolated ligament tissue. It is hypothesized that some portion of the natural ligament was scarified during harvesting and for the purpose of gripping (for tensile testing). Hence, the total elongation of the ligament at failure was lesser than in the current study. In another study, Chandrashekar et al. [5] experimented on ligament with bone plugs at $45^{\circ}$ to the longitudinal axis of ACL. In this case, the ligament is already pre-stretched and, therefore, the total elongation was lesser than the current study. Other research groups [21], [28], [30] who have studied FATC samples have not reported the values of elongation at failure. As all soft tissues other than ACL were removed from the knee joint in the present study, the ACL tissue is strain-free as compared to the intact knee (i.e., knee with all other ligaments in place). The above points are the rationale for higher value of elongation at failure as reported in the current study.

Uniform and reproducible gripping of the nonuniform as well as slippery surface is quite challenging. Studies on variable rate of strain of human ACL or FATC is scarce. Further, biomechanical studies of human biological tissues are quite challenging due the unavailability of a large number of similar samples, variations in medical history and non-standard sizes of human tissues, thereby demanding customized solutions [9]. 


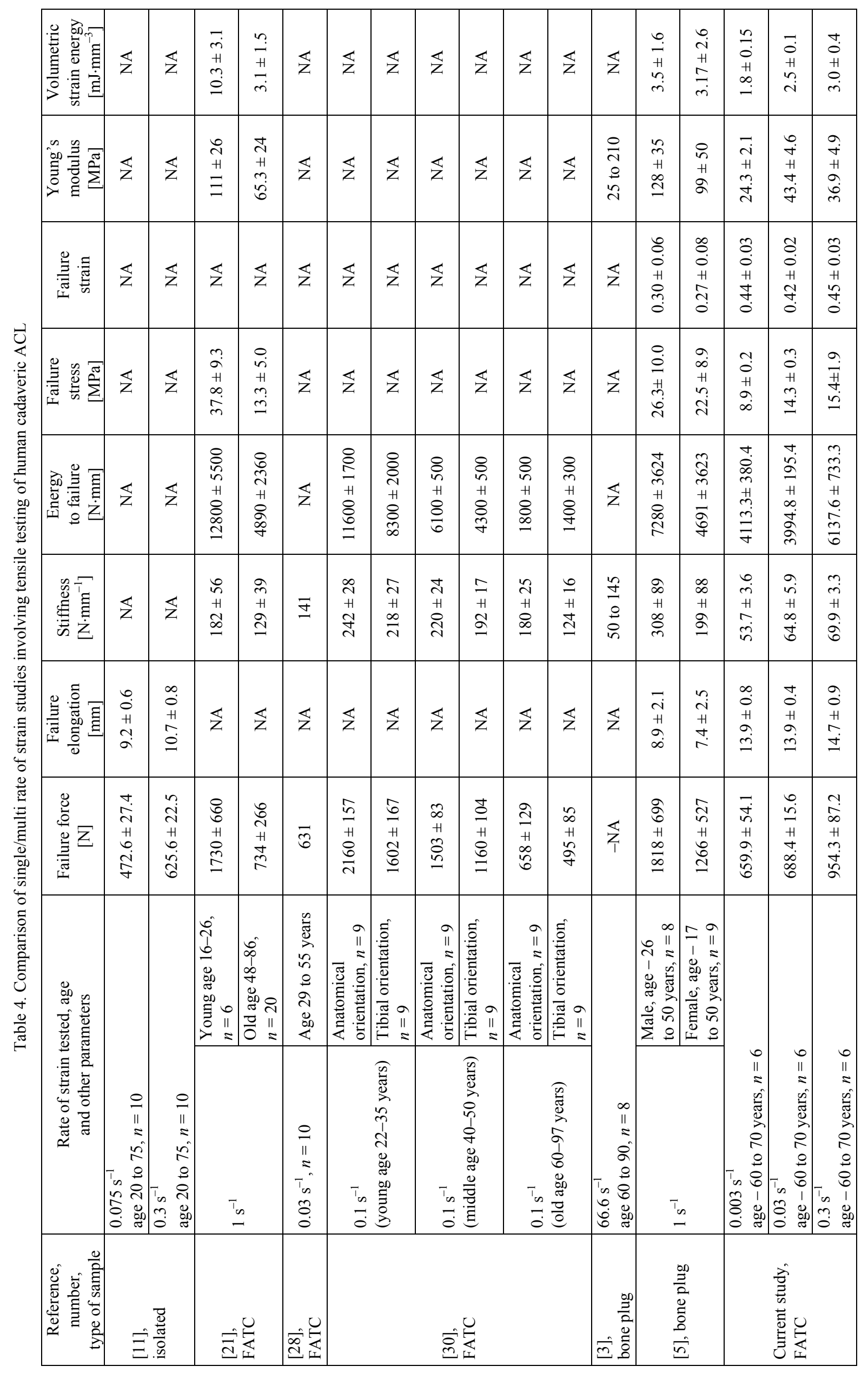


Several three-dimensional visco-hyperelastic models provide us the relation between rate of strain and the mechanical behaviour [10], [22], [29]. Danto and Woo used a simple exponential function with two constants to curve fit the experimental stress-strain data obtained at various rates of strain [8]. Pioletti et al., Limbert and Middleton had proposed phenomenological models on the basis of the experiment, however, without any correlation or correspondence with the structural elements of the material [14], [22]. De Vita and Slaughter proposed a structural model for expressing stress on the ligament as a function of rate of strain [29]. The parameters used in the structural models are related to the structure of tissue. Hence, structural models are more advanced than phenomenological models as the tissue morphology is taken into account.

Experimental force-length characteristics of any connective tissue can be used by researchers to predict force-length characteristics at user-defined rate of strain provided the appropriate constitutive equation is available. There are a few limitations to the study. The failure force reported in this work is not a measure of the failure force occurring during ACL injury in live subjects. The anatomical angle of the femur and tibia were not maintained as only axial testing of ACL was the purpose of the study. The highest rate of strain reported in the experimental section is limited by the maximum crosshead speed of the testing machine. Only cadavers of subjects in a small range in age were used for this study. In future studies, the same sample may be tested at multiple rates of strain within the yield point to eliminate sample based variations. Reproducibility of the sample loading in the linear region may also be verified.

\section{Conclusions}

Tensile tests carried out on fresh human cadaveric FATC at approximately three orders of rates of strain caused noticeable variations in the force-length behaviour. Stiffness, failure stress, Young's modulus and volumetric strain energy were observed to increase significantly at higher rates of strain tested. The nonlinear viscoelasticity was modeled using De Vita and Slaughter's parameters. The model was validated via additional experimental tests conducted at different rates of strain. This validated model can be used to simulate the force-length behaviour in linear region for dynamic activities of live subjects involving multiple rates of strain. This study has focused on conduct- ing experiments on fresh human cadaveric FATCs to obtain the tensile properties and parameters for an established De Vita and Slaughter rate of strain structural model.

\section{Ethical approval for the study}

Ethical approval for this study was obtained from the Institute Ethics Committee of All India Institute of Medical Sciences (AIIMS) Delhi (reference number: IEC/NP/-332/07.08.2015 and IEC-637/03.11.2017, RP-29/2017). The samples from fresh-frozen cadavers were obtained during the autopsy of unclaimed bodies. The anatomy act of 1959 (Indian government), allows for usage of human dead body for teaching and research activities when (i) death happens in a state-run government hospital or in a public place within the prescribed zone of the hospital or (ii) police had clarified that the body is unclaimed (declared after 48 hours) [26].

\section{References}

[1] AhSANizAdeh S., Li L., Visco-hyperelastic constitutive modeling of soft tissues based on short and long-term internal variables, Biomed. Eng. Online, 2015, 14, 29.

[2] Arendt E.A., Agel J., Dick R., Anterior cruciate ligament injury patterns among collegiate men and women, J. Athl. Train., 1999, 34, 86-92.

[3] Arnoux P.J., Cavallero C., Chabrand P., Brunet C., Knee ligament failure under dynamic loadings, Int. J. Crashworthiness, 2002, 7, 255-268.

[4] Bonner T.J., Newell N., Karunaratne A., Pullen A.D., Amis A.A., Bull A.M.J., Masouros S.D., Strain-rate sensitivity of the lateral collateral ligament of the knee, J. Mech. Behav. Biomed. Mater., 2015, 41, 261-270.

[5] Chandrashekar N., Mansouri H., Slauterbeck J., HASHEMI J., Sex-based differences in the tensile properties of the human anterior cruciate ligament, J. Biomech., 2006, 39, 2943-2950.

[6] Corder G.W., Foreman D.I., Nonparametric Statistics for Non-Statisticians, A Step-by-Step Approach, 2011.

[7] Crowninshield R.D., Pope M.H., The strength and failure characteristics of rat medial collateral ligaments, J. Trauma., 1976, 16, 99-105.

[8] Danto M.I., Woo S.L.Y., The mechanical properties of skeletally mature rabbit anterior cruciate ligament and patellar tendon over a range of strain rates, J. Orthop. Res., 1993, 11, 58-67.

[9] FunG Y.C., Biomechanics, Springer-Verlag, 1981.

[10] Holzapfel G., Nonlinear solid mechanics: A continuum approach for engineering, 1st ed., Work, 2000, 455.

[11] Kennedy J.C., Hawkins R.J., Willis R.B., DanYlchuck K.D., Tension studies of human knee ligaments. Yield point, ultimate failure, and disruption of the cruciate and tibial collateral ligaments, J. Bone Joint Surg. Am., 1976, 58, 350-355.

[12] Kiapour A.M., Kiapour A., Goel V.K., Quatman C.E., Wordeman S.C., Hewett T.E., Demetropoulos C.K., Unidirectional coupling between tibiofemoral frontal and axial plane rotation supports valgus collapse mechanism of $A C L$ injury, J. Biomech., 2015, 48, 1745-1751. 
[13] Levine J.W., Kiapour A.M., Quatman C.E., Wordeman S.C., Goel V.K., Hewett T.E., Demetropoulos C.K., Clinically relevant injury patterns after an anterior cruciate ligament injury provide insight into injury mechanisms, Am. J. Sports Med., 2014, 41, 385-395.

[14] Limbert G., Middleton J., A transversely isotropic viscohyperelastic material Application to the modeling of biological soft connective tissues, Int. J. Solids Struct., 2004, 41, 4237-4260.

[15] Marieswaran M., Jain I., Garg B., Sharma V., KalyanASUNDARAm D., A Review on Biomechanics of Anterior Cruciate Ligament and Materials for Reconstruction, Appl. Bionics Biomech., 2018, 1-14.

[16] McLean S.G., Mallett K.F., ArRuda E.M., Deconstructing the anterior cruciate ligament: what we know and do not know about function, material properties, and injury mechanics, J. Biomech. Eng., 2015, 137, 020906.

[17] Mo F., Arnoux P.J., Cesari D., Masson C., The failure modelling of knee ligaments in the finite element model, Int. J. Crashworthiness, 2012, 17, 630-636.

[18] Mo F., ARnoux P.J., Cesari D., Masson C., Investigation of the injury threshold of knee ligaments by the parametric study of car-pedestrian impact conditions, Saf. Sci., 2014, 62, 58-67.

[19] Mo F., Masson C., Cesari D., Arnoux P.J., Coupling Lateral Bending and Shearing Mechanisms to Define Knee Injury Criteria for Pedestrian Safety, Traffic Inj. Prev., 2013, 14, 378-386.

[20] Noyes F.R., DeLucas J.L., TorviK P.J., Biomechanics of anterior cruciate ligament failure: an analysis of strain-rate sensitivity and mechanisms of failure in primates, J. Bone Joint Surg. Am., 1974, 56, 236-53.

[21] Noyes F.R., GRoOD E.S., The strength of the anterior cruciate ligament in humans and Rhesus monkeys, J. Bone Joint Surg. Am., 1976, 58, 1074-1082.

[22] Pioletti D.P., Rakotomanana L.R., Benvenuti J.F., LeYvraz P.F., Viscoelastic constitutive law in large deformations: Application to human knee ligaments and tendons, J. Biomech., 1998, 31, 753-757.

[23] Pioletti D.P., Rakotomanana L.R., Leyvraz P.F., Strain rate effect on the mechanical behavior of the anterior cruciate ligament-bone complex, Med. Eng. Phys., 1999, 21, 95-100.

[24] Schumacher T.C., Tushtev K., Wagner U., Becker C., große Holthaus M., Hein S.B., HaAck J., Heiss C., Engelhardt M., El Khassawna T., Rezwan K., A novel, hydroxyapatite-based screw-like device for anterior cruciate ligament (ACL) reconstructions, Knee, 2017.

[25] Shelburne K.B., Kim H.J., Sterett W.I., Pandy M.G., Effect of posterior tibial slope on knee biomechanics during functional activity, J. Orthop. Res., 2011, 29, 223-231.

[26] Subramanium, Law inrelation to medical men, [in:] Med. Jurisprud. Toxicol., Butterworths, New Delhi, 1999.

[27] Taylor D.C., Dalton J.D., Seaber A. V, Garrett W.E., Viscoelastic properties of muscle-tendon units, Am. J. Sports Med., 1990, 18, 300-309.

[28] TRENT P.S., P WalKer.S., Wolf B., Ligament length patterns, strength, and rotational axes of the knee joint, Clin. Orthop. Relat. Res., 1976, 263-270.

[29] De Vita R., Slaughter W.S., A structural constitutive model for the strain rate-dependent behavior of anterior cruciate ligaments, Int. J. Solids Struct., 2006, 43, 15611570.

[30] Woo S.L.Y., Hollis J.M., AdAMS D.J., LyON R.M., TAKaI S., Tensile properties of the human femur-anterior cruciate liga- ment-tibia complex the effects of specimen age and orientation, Am. J. Sport. Med., 1991, 19, 217-225.

\section{Supplementary information}

\section{S1. Design of cylindrical gripper}

Both femur and tibia are irregularly tapered long bones, with larger dimensions at the epiphysis (extreme ends) than the diaphysis (mid-section). The dimensions of the bones can vary to a maximum of $30 \%$ amongst subjects. Therefore, to grip larger bones, larger forces shall be employed to avoid slippage at higher rates of strain. Bones can potentially be crushed when larger perpendicular forces are applied via a conventional screw gripper. As higher clamping force cannot be used, screw grippers are ruled out. Wedge type of grippers is another type of commonly used gripper. Owing to the direction of the taper in the bones, wedge grippers are not suitable for such geometry. Holes of diameter $6.5 \mathrm{~mm}$ were drilled into the femur and tibia in coronal plane in line with ACL tissue at approximately $90-120 \mathrm{~mm}$ apart each for insertion of metallic rods. The tensile forces on the samples were applied via metallic rods punctured through the bones [S2]. It is evident that the rods used for pulling the femur and tibia apart, need a structural frame to distribute the load. The metallic rods can either be supported on to a plate holder [S3] or by other designs of the gripper. The cylindrical gripper (Fig. S1) fabricated in-house transforms the bending forces into circumferential stress. The anterio-posterior diameter and medio-lateral diameter of distal femur for Indian population are no more than $80 \mathrm{~mm}$ [S5]. For the ease of handling, the inner diameter was fixed at $5 \mathrm{inch}$. The bones can be easily clamped and de-clamped in the cylindrical gripper with the rods. The cylindrical gripper was fabricated using EN 31 and the rods were made of hardened steel. The cylindrical gripper was finally chrome plated. The portion of gripper attached to the UTM was machined as such it fits precisely to the machine.

\section{S2. Modeling of rate of strain behaviour}

A structural constitutive equation developed by De Vita and Slaughter was adopted in this work to 
model the rate of strain dependent force-length behaviour of the ACL [S6]. The constitutive law was derived from earlier model of Lanir [S1]. Tissue anisotropy, non-linearity and incompressibility combined with rate of strain were accounted for in the model. Collagen fibers of the ACL were assumed to be the significant load-bearing component of the tissue. Before loading, the fibers were oriented in different directions. The fibers gradually become taut upon loading, by fiber-recruitment process. The fiber recruitment has been represented statistically by probability density functions. A three-parametric Weibull model was used to define the probability distribution of uncrimping of the collagen fibers. The detail structural constitutive modeling for dense connective tissue is available in the previous work of the authors [S4]. The taut collagen fibers were modeled by Kelvin-Voigt-type viscoelastic behaviour. The model assumes that ligamentous tissue endures an isochoric and axisymmetric deformation. The model provides a relation between nominal axial stress $P_{Z Z}$ as a function of rate of strain $\dot{\varepsilon}$ and logarithmic axial strain $\varepsilon_{S}$

$$
P_{Z Z}=\int_{0}^{\varepsilon} \alpha \beta^{-\alpha} \varepsilon_{S}^{(\alpha-1)} e^{-\left(\frac{\varepsilon_{S}}{\beta}\right)^{\alpha}}\left[K\left(\varepsilon-\varepsilon_{S}\right)+\eta \dot{\varepsilon}\right] d \varepsilon_{S},
$$

$$
\begin{gathered}
F=P_{Z Z} A, \\
\lambda=\left(e^{\varepsilon_{S}}-1\right) \times L_{0} .
\end{gathered}
$$

Table S1. Resting length and cross-sectional area of samples tested at three rates of strain

\begin{tabular}{|c|c|c|}
\hline $\begin{array}{c}\text { Rate of strain } \\
\text { tested }\left[\mathrm{s}^{-1}\right]\end{array}$ & $\begin{array}{c}\text { Resting length } \\
\text { of ACL [mm] }\end{array}$ & $\begin{array}{c}\text { Cross-sectional } \\
\text { area of ACL }\left[\mathrm{mm}^{2}\right]\end{array}$ \\
\hline 0.003 & $31.50 \pm 0.66$ & $74.00 \pm 5.77$ \\
\hline 0.03 & $32.33 \pm 0.84$ & $48.33 \pm 0.96$ \\
\hline 0.3 & $32.43 \pm 0.77$ & $65.16 \pm 7.38$ \\
\hline
\end{tabular}

The constants $\alpha$ and $\beta$ relate to the sequential straightening of collagen fibers as the tissue elongates and the constants represent the probability distribution function for sequential straightening of collagen fibers under tensile loading. The constant $K$ defines the elastic modulus of collagen fibers, while $\eta$ represents the absolute viscosity. The tensile behaviour within the lower limit of 0.003 and the upper limit of $0.3 \mathrm{~s}^{-1}$ can be modeled using the equation with the values of the parameters $(\alpha, \beta, K, \eta)$. Experimental data is available at three orders of rates of strain within the abovementioned limits. Equation (S1) was used to model the behaviour of the ligament at other rates of strain. The instantaneous force was calculated by Eq. (S2).

Table S2. Structural properties of FATC specimens tested at $0.003,0.03,0.3 \mathrm{~s}^{-1}$.

FI - Femoral insertion failure,

MS - Midsection failure, TI - Tibial insertion failure

\begin{tabular}{|c|c|c|c|c|c|c|}
\hline Sample & $\begin{array}{c}\text { Rate } \\
\text { of strain tested } \\
{\left[\mathrm{s}^{-1}\right]}\end{array}$ & $\begin{array}{c}\text { Failure force } \\
{[\mathrm{N}]}\end{array}$ & $\begin{array}{c}\text { Failure elongation } \\
{[\mathrm{mm}]}\end{array}$ & $\begin{array}{c}\text { Stiffness } \\
{[\mathrm{N} / \mathrm{mm}]}\end{array}$ & $\begin{array}{c}\text { Energy for failure } \\
{[\mathrm{N} \text { mm }]}\end{array}$ & $\begin{array}{c}\text { Point } \\
\text { of rupture }\end{array}$ \\
\hline S1 & 0.003 & 440.50 & 14.20 & 42.94 & 3245.48 & FI \\
\hline S2 & 0.003 & 621.00 & 14.33 & 51.74 & 4280.45 & TI \\
\hline S3 & 0.003 & 660.80 & 10.71 & 69.19 & 2919.28 & FI \\
\hline S4 & 0.003 & 841.00 & 16.69 & 48.03 & 5449.92 & TI \\
\hline S5 & 0.003 & 735.00 & 14.73 & 54.77 & 4702.89 & TI \\
\hline S6 & 0.003 & 661.50 & 13.13 & 55.81 & 4082.08 & FI \\
\hline S7 & 0.03 & 671.30 & 15.33 & 56.25 & 4416.1 & FI \\
\hline S8 & 0.03 & 756.80 & 13.73 & 72.05 & 4495.50 & FI \\
\hline S9 & 0.03 & 692.64 & 13.21 & 87.20 & 4191.19 & MS \\
\hline S10 & 0.03 & 645.60 & 12.85 & 70.45 & 3256.41 & TI \\
\hline S11 & 0.03 & 667.50 & 13.01 & 56.46 & 3628.34 & MS \\
\hline S12 & 0.03 & 696.80 & 15.61 & 46.81 & 3981.31 & TI \\
\hline S13 & 0.3 & 1115.00 & 16.89 & 61.80 & 7234.22 & FI \\
\hline S14 & 0.3 & 876.00 & 16.44 & 60.90 & 6665.80 & FI \\
\hline S15 & 0.3 & 1076.00 & 15.11 & 80.56 & 7391.88 & TI \\
\hline S16 & 0.3 & 1173.00 & 14.51 & 77.69 & 7134.40 & TI \\
\hline S17 & 0.3 & 594.00 & 10.21 & 72.57 & 2687.34 & TI \\
\hline S18 & 0.3 & 892.00 & 15.51 & 66.00 & 5712.25 & TI \\
\hline
\end{tabular}


Table S3. Material properties of FATC specimens tested at $0.003,0.03$ and $0.3 \mathrm{~s}^{-1}$

\begin{tabular}{|c|c|c|c|c|c|}
\hline Sample & $\begin{array}{c}\text { Rate of strain } \\
\text { tested }\left[\mathrm{s}^{-1}\right]\end{array}$ & $\begin{array}{c}\text { Failure stress } \\
{[\mathrm{MPa}]}\end{array}$ & Failure strain & $\begin{array}{c}\text { Young's modulus } \\
{[\mathrm{MPa}]}\end{array}$ & $\begin{array}{c}\text { Volumetric strain } \\
\text { energy }\left[\mathrm{mJ} / \mathrm{mm}^{3}\right]\end{array}$ \\
\hline S1 & 0.003 & 8.81 & 0.44 & 27.53 & 2.02 \\
\hline S2 & 0.003 & 8.63 & 0.47 & 21.23 & 1.98 \\
\hline S3 & 0.003 & 8.25 & 0.31 & 30.87 & 1.07 \\
\hline S4 & 0.003 & 8.76 & 0.55 & 15.69 & 1.89 \\
\hline S5 & 0.003 & 9.18 & 0.44 & 24.40 & 1.78 \\
\hline S6 & 0.003 & 10.02 & 0.43 & 26.63 & 2.06 \\
\hline S7 & 0.03 & 15.25 & 0.43 & 40.90 & 2.86 \\
\hline S8 & 0.03 & 15.13 & 0.45 & 43.55 & 2.99 \\
\hline S9 & 0.03 & 13.85 & 0.41 & 57.28 & 2.61 \\
\hline S10 & 0.03 & 14.34 & 0.36 & 55.75 & 2.26 \\
\hline S11 & 0.03 & 13.35 & 0.40 & 35.72 & 2.65 \\
\hline S12 & 0.03 & 13.93 & 0.52 & 27.71 & 3.03 \\
\hline S13 & 0.3 & 14.48 & 0.54 & 25.90 & 2.24 \\
\hline S14 & 0.3 & 8.84 & 0.54 & 18.54 & 4.76 \\
\hline S15 & 0.3 & 21.52 & 0.48 & 45.87 & 3.39 \\
\hline S16 & 0.3 & 19.55 & 0.41 & 42.00 & 1.55 \\
\hline S17 & 0.3 & 11.88 & 0.29 & 48.78 & 3.20 \\
\hline S18 & 0.3 & 16.51 & 0.47 & 40.77 & \\
\hline
\end{tabular}

The symbol $A$ refers to the average area of the ligament tissue. The average cross-sectional area of ACL (across samples) was used. The elongation in ACL was defined as an exponential function of strain $\left(\varepsilon_{S}\right)$ and resting length $\left(L_{0}\right)$ as depicted in Eq. (S3). An average resting length $(30 \mathrm{~mm})$ was assigned to the ligament in the model and was defined as the length of ACL at $0^{\circ}$ of flexion, $0^{\circ}$ of rotation and $0^{\circ}$ of adduction for the study.

\section{References for supplementary information}

[S1] LANIR Y., Constitutive equations for fibrous connective tissues, J. Biomech., 1983, 16, 1-12.
[S2] Noyes F.R., DeLuCAS J.L., ToRviK P.J., Biomechanics of anterior cruciate ligament failure: an analysis of strain-rate sensitivity and mechanisms of failure in primates, J. Bone Joint Surg. Am., 1974, 56, 236-253.

[S3] Noyes F.R., DeLucas J.L., ToRviK P.J., Biomechanics of anterior cruciate ligament failure: an analysis of strain-rate sensitivity and mechanisms of failure in primates, J. Bone Joint Surg. Am., 1874, 56, 236-53.

[S4] SiKIDAR A., Kalyanasundaram D., An open-source plugin for OpenSim ${ }^{\circledR}$ to model the non-linear behaviour of dense connective tissues of the human knee at variable strain rates, Comput. Biol. Med., 2019, 110, 186-195.

[S5] Vaidya S.V., Ranawat C.S., ArRojIS A., Laud N.S., Anthropometric Measurements to Design Total Knee Prostheses for the Indian Popluation, J. Arthroplasty, 2000, 15.

[S6] De VITA R., SLAUghteR W.S., A structural constitutive model for the strain rate-dependent behavior of anterior cruciate ligaments, Int. J. Solids Struct., 2006, 43, 1561-1570. 